\title{
KAITAN BANTUAN LANGSUNG MASYARAKAT (BLM) PENGEMBANGAN USAHA AGRIBISNIS PERDESAAN (PUAP) DENGAN TINGKAT KEBERHASILAN KEGIATAN USAHATANI DI GAPOKTAN KOTA JAMBI
}

\author{
Nuri Trioni ${ }^{1}$, Ernawati HD ${ }^{2}$ dan Yanuar Fitri ${ }^{2}$ \\ ${ }^{1}$ Alumni Program Studi Agribisnis Fakultas Pertanian Universitas Jambi \\ ${ }^{2}$ Staf Pengajar Program Studi Agribisnis Fakultas Pertanian Universitas Jambi \\ Email: Nuritrioni@yahoo.co.id
}

\begin{abstract}
ABSTRAK
Penelitian ini dilakukan untuk mengetahui gambaran umum dan kegiatan gabungan kelompok tani pada pengelolaan dana pengembangan usaha agribisnis perdesaan, serta tingkat keberhasilan kegiatan usahatani anggota gabungan kelompok tani pada pengembangan usaha agribisnis perdesaan. Metode penarikan sampel yang digunakan adalah metode cluster sampling. Analisis data menggunakan analisis deskriptif yang di ukur untuk menganalisis pendapatan masing-masing komoditi pada kegiatan pengembangan usaha agribisnis perdesaan. Hasil pembahasan diketahui bahwa modal usaha yang disalurkan melalui gabungan kelompok tani yaitu sebesar Rp. 100 juta rupiah untuk dimanfaatkan anggota gabungan kelompok tani pada sarana produksi pertanian, kegiatan gabungan kelompok tani pada pengelolaan dana pengembangan usaha agribisnis perdesaan yaitu melalui penyusunan rencana usaha anggota, rencana usaha kelompok, rencana usaha bersama yang bertujuan untuk memperoleh bantuan langsung masyarakat dengan memenuhi syarat dokumen administrasi yang akan di periksa oleh tim teknis pengembangan usaha agribisnis perdesaan, dan tingkat keberhasilan kegiatan usahatani anggota gabungan kelompok tani pada pengembangan usaha agribisnis perdesaan dinilai dari tercapainya keperluan sarana produksi pertanian yang dilihat dari keadaan kelompok tani, luas lahan petani, biaya produksi yang dikeluarkan, produksi usahatani, penerimaan usahatani, serta meningkatnya pendapatan petani. Rata-rata pendapatan anggota gabungan kelompok tani di Kelurahan Lingkar Selatan yaitu sebesar Rp. 1.939.322,53 setiap musimnya dan di Kelurahan Mudung Laut rata-rata pendapatan anggota gapoktan yaitu sebesar Rp. 3.948.505,22 tiap musimnya.
\end{abstract}

\section{Kata Kunci : Pengembangan Usaha Agribisnis Perdesaan (PUAP), Anggota Gapoktan, Kegiatan usahatani, Pendapatan}

\section{ABSTRACT}

This research was conducted to determine an overview of the rural agribusiness venture development program, and the level of success to activity the farmers is a member of the combined group of farmers in rural agribusiness venture development. This research used cluster sampling methods, the analysis data using of descriptive analysis in measure to analyze the income of each commodity in rural agribusiness venture development activities. The results of this research of the mind that venture capital that is channeled through a combined group of farmers is about Rp. 100 million rupiah's for the exploited members of the combined group of farmers on the means of agricultural production, the combined activities of farmers groups at the Fund management business development rural agribusiness through the preparation of business plans, members of the group, plans a joint venture that aims to obtain immediate relief society with qualified administrative documents which will be in check of technical team the rural agribusiness venture development, and the success rate of farming activities members of combined group of farmers the rural agribusiness venture development judged from the achievement of the purposes of the means of agricultural production, which is seen from a State of farmer groups, land area farmers, production costs were excluded, the production of farming, the acceptance of farming, as well as increasing the income of farmers. The averageof amount the jambi's group of farmerin lingkar selatan's village is about Rp. 1.939.322,53 every mount's and Rp 3.948.505,22 every mounts in mudung laut's village.

Keywords : the rural agribusiness venture development , combined Jambi's group of farmers, farm, income. 


\section{PENDAHULUAN}

Permodalan masih menjadi salah satu permasalahan utama yang dihadapi pelaku usaha pertanian. Untuk mengatasi permasalahan permodalan Pemerintah memberikan solusi dengan meluncurkan suatu program Pengembangan Usaha Agribisnis Perdesaan (PUAP) melalui pemberian dana Bantuan Langsung Masyarakat (BLM) sebagai modal usahatani bagi petani, sekaligus untuk memperbaiki dan memperkuat kelembagaan ekonomi yang pada akhirnya bermuara pada berkembangnya Lembaga Keuangan Mikro Agribisnis (LKMA).

Pemanfaatan dana BLM-PUAP disalurkan untuk kegiatan usahatani yang meliputi pembelian sarana produksi (saprodi) yaitu pengadaan bibit, pupuk, obat-obatan dan untuk menunjang keberhasilan usaha yang dikembangkan dalam bidang pertanian. Daerah penelitian diperoleh melalui pertimbangan bahwa di antara 26 Kelurahan pada 6 Kecamatan Kota Jambi, Kelurahan Lingkar Selatan dan Kelurahan Mudung Laut merupakan salah satu kelurahan yang banyak berkontribusi dalam mengembangkan hasil pertanian. Sebagian besar penduduk di Kecamatan Jambi Selatan bermata pencaharian sebagai petani sayuran dan sebagian besar penduduk di Kecamatan Pelayangan bermata pencaharian sebagai petani padi sawah. Namun secara umum dari segi fungsinya pemberian modal BLM-PUAP diharuskan untuk petani yang mengusahakan usahatani di ragam usahatani. Pemerintah dituntut untuk dapat menciptakan program penguatan modal yang benar-benar bermanfaat bagi petani, sekaligus tidak membebankan petani. Program PUAP ditujukan untuk petani dengan bunga ringan, terjangkau oleh petani serta pemberian kredit usahatani benar-benar digunakan untuk keberhasilan kegiatan produktif dibidang pertanian (Badan Pusat statistic. 2013).

Upaya pemberian modal dalam bentuk kredit pada usahatani terus diprogramkan guna membantu pemenuhan kebutuhan petani, apabila kredit dapat memenuhi harapan petani maka otomatis petani akan menanggapi positif terhadap kredit yang diberikan, sehingga selain kredit usahatani dapat membantu kelangsungan usahatani, tingkat kepercayaan petani terhadap kredit program Pemerintah akan meningkat (Siadari, 2015). Penelitian ini bertujuan untuk mengetahui gambaran umum program Pengembangan Usaha Agribisnis Perdesaan (PUAP), mengetahui kegiatan Gapoktan dalam pengelolaan Dana PUAP dan untuk mengetahui tingkat keberhasilan kegiatan usahatani Anggota Gapoktan pada Pengembangan Usaha Agribisnis Perdesaan (PUAP).

\section{METODE PENELITIAN}

Penelitian ini dilaksanakan di Kecamatan Jambi Selatan dan Kecamatan Pelayangan Kota Jambi. Daerah penelitian diperoleh dengan sengaja (purposive) yaitu dengan pertimbangan bahwa di dua kecamatan tersebut telah menerima dana BLM-PUAP dan mengembangkan usahatani di bidang agribisnis serta sebagai salah satu kecamatan penghasil usahatani yang beragam baik di bidang usahatani padi sawah, palawija, maupun sayursayuran yang cukup besar). Penetapan lokasi penelitian di Kelurahan Lingkar Selatan dan Kelurahan Mudung Laut karena penerimaan dana BLM-PUAP di tahun yang sama yaitu Tahun 2009, dibandingkan kelurahan lainnya yang menerima dana BLM-PUAP di tahun yang berbeda. Jumlah populasi sasaran yaitu berdasarkan teknik cluster sampling yaitu petani yang melakukan kegiatan usahatani padi, palawija, dan sayuran tergabung dalam kelompok tani. Menurut informasi Balai Penyuluh Pertanian (BPP) Kecamatan Pelayangan dan PPL setempat pada Kelurahan Mudung Laut jumlah Anggota Gapoktan sebanyak 80 anggota yang melakukan kegiatan ragam usahatani. Selanjutnya pada Balai Penyuluh Pertanian (BPP) Kecamatan Jambi Selatan dan PPL setempat pada Kelurahan Lingkar Selatan jumlah Anggota 
Gapoktan sebanyak 117 anggota yang juga melakukan kegiatan usahatani sayuran. Sebagian besar Anggota Gapoktan pada Gapoktan Tani Makmur adalah petani sayuran sedangkan Gapoktan Sehati sebagian besar berusahatani padi sawah. Penentuan sampel dalam penelitian ini menggunakan rumus slovin dalam (Ridwan dan Akdon, 2009), yaitu dengan ketentuan apabila sampel lebih dari 100 orang maka presisi dapat diambil $10 \%-15 \%$ atau $20 \%-25 \%$ atau lebih. Pada penelitian ini jumlah objek lebih dari 100 orang maka presisi yang akan diambil sebesar 10\%, sehingga jumlah ukuran sampelnya sebanyak 66 responden dengan jumlah sampel di Kelurahan Lingkar Selatan sebesar 39 responden dan Kelurahan Mudung Laut sebesar 27 responden. Cara menganalisis data yaitu dengan analisis deskriptif yang diukur untuk menganalisis pendapatan.

Untuk menghitung penerimaan digunakan formulasi sebagai berikut : TR $=\mathrm{Py} \times \mathrm{Qi}$, untuk menghitung biaya digunakan formulasi sebagai berikut : $\mathrm{TC}=\mathrm{FC}+\mathrm{VC}$, untuk menganalisa pendapatan digunakan formulasi sebagai berikut : $\mathrm{Pd}=\mathrm{TR}-\mathrm{TC}$

\section{HASIL DAN PEMBAHASAN}

\section{Gambaran Umum dan Kegiatan Gapoktan di Kecamatan Jambi Selatan dan Kecamatan Pelayangan Kota Jambi.}

Pada Tahun 2008, pemerintah membuat sebuah program dalam rangka meningkatkan taraf hidup petani melalui Program Pengembangan Usaha Agribisnis Perdesaan (PUAP). Program ini berupa pemberian bantuan modal usaha tani yang akan dikelola oleh lembaga Gapoktan. Gapoktan Tani Makmur dan Gapoktan Sehati menjadi salah satu penerima bantuan Dana PUAP. Maka dibentuklah Gapoktan yang terdiri dari beberapa kelompok tani yang sudah ada dan sudah tergabung sebelumnya.

Program PUAP mulai memasuki tiap kelurahan di Kota Jambi pada Tahun 2009 dengan tujuan untuk memudahkan pemberian dana tepat sasaran dan tepat waktu setelah peluncuran Program PUAP di tahun 2008, dikhususkan pada tiap Gapoktan yang mengusulkan Dana PUAP serta berbentuk Bantuan Langsung Masyarakat (BLM) untuk dialokasikan kembali kepada Anggota Gapoktan yang tergabung dalam kelompok tani, BLM yang disalurkan merupakan dana hibah bersyarat dalam artian Dana PUAP tidak perlu dikembalikan ke Departemen Pertanian, melainkan secara terus menerus akan tetap berlangsung dengan syarat Anggota Gapoktan yang mendapatkan dana PUAP harus mengembalikannya dalam waktu yang telah ditentukan sehingga Dana PUAP dapat terus digulirkan dan dikembangkan.

Dana PUAP yang disalurkan adalah senilai Rp. 100 juta untuk tiap Kelurahan/Gapoktan terpilih, BLM-PUAP disalurkan ke Gapoktan yang sudah dibentuk selama minimal 3 tahun serta memiliki kelompok tani. Salah satu Gapoktan penerima Dana BLM-PUAP adalah Gapoktan Tani Makmur Kecamatan Jambi Selatan dan Gapoktan Sehati Kecamatan Pelayangan Kota Jambi yang menerima Dana BLM-PUAP di tahun yang sama yaitu pada Tahun 2009. Komoditas utama Gapoktan Tani Makmur yaitu usahatani sayursayuran meliputi usahatani kacang panjang, kangkung, bayam, sawi, selada, pare, timun, pakcoi, kembang kol, seledri dan kemangi, kemudian pada Gapoktan Sehati komoditas utama yaitu sebagian besar petani melakukan usahatani padi sawah karena luas areal tanamnya paling besar diantara komoditas lainnya akan tetapi petani juga berusahatani sayuran dengan tujuan untuk penambahan pendapatan petani yang meliputi kacang panjang, pare, dan timun 


\section{Karakteristik Gapoktan Tani Makmur dan Gapoktan Sehati di Kecamatan Jambi Selatan dan Kecamatan Pelayangan Kota Jambi}

Gabungan Kelompok Tani (Gapoktan) di Kecamatan Jambi Selatan telah berdiri pada Tahun 2002 dan di Gapoktan Sehati berdiri pada Tahun 2005. Pendirian semua Gapoktan di daerah penelitian dibentuk atas dasar rekomendasi oleh penyuluh pendamping di kelurahan setempat untuk mensosialisasikan Program Pengembangan Usaha Agribisnis Perdesaan (PUAP), selain itu tujuan lain adalah untuk meningkatkan kesejahteraan petani sebagai salah satu wadah kerjasama baik antar anggota maupun antar kelompok, dan sebagai wadah informasi teknologi inovasi baru tentang pertanian yang dapat mempermudah jalannya kegiatan pertanian ataupun dalam meningkatkan produksi yang mampu mengembangkan pembangunan pertanian.

\section{Keanggotaan Gapoktan Tani Makmur dan Gapoktan Sehati}

Keanggotaan Gapoktan memiliki latar belakang yang sama. Mayoritas masyarakatnya bermata pencaharian sebagai petani. Namun yang membedakan adalah jenis usahatani yang dikelola, salah satu mata pencaharian pokok masyarakat di Gapoktan Tani Makmur yaitu usahatani sayuran sedangkan di Gapoktan Sehati mayoritas masyarakatnya adalah petani padi sawah walaupun juga diselingi oleh usahatani sayuran, selain itu ada pula kerjasama antar Gapoktan di daerah penelitian dalam hal pengelolaan usahatani sayuran, pada Gapoktan Sehati dikhususkan untuk berusahatani sayuran yang identik dengan sayuran berjenis buah dan keras seperti pare, timun, dan kacang panjang. Hal ini dilakukan agar harga sayuran di Gapoktan Tani Makmur khususnya Kecamatan Jambi Selatan tidak turun mengalami penurunan harga di pasaran, karena apabila petani di Gapoktan Sehati Kecamatan Pelayangan juga mengusahakan usahatani sayur-sayuran seperti bayam, kangkung, kembang kol, seledri, kemangi, dan lain sebagainya yag identik di usahakan di Kecamatan Jambi Selatan maka produksi akan meningkat dan harga juga menjadi rendah.

\section{Kegiatan Gapoktan Pada Pengelolaan Dana Pengembangan Usaha Agribisnis Perdesaan (PUAP) di Gapoktan Tani Makmur dan Gapoktan Sehati}

Kegiatan yang dilakukan oleh pengurus Gapoktan ataupun Anggota Gapoktan di Gapoktan Tani Makmur dan Gapoktan Sehati dalam upaya mendukung pelaksanaan program PUAP yaitu penyusunan RUA (Rencana Usaha Anggota), RUK (Rencana Usaha Kelompok), RUB (Rencana Usaha Bersama), penyusunan RUA, RUK, dan RUB oleh pengurus dan Anggota Gapoktan bertujuan untuk memperoleh Bantuan Langsung Masyarakat (BLM).

Gabungan Kelompok Tani (Gapoktan) di daerah penelitian menerima Dana BLMPUAP sebanyak Rp. 100 juta pada Tahun 2009 yang berjumlah 4 kelompok tani di Gapoktan Tani Makmur dan 8 Kelompok Tani di Gapoktan Sehati. Bentuk struktur kepengurusan Gapoktan sebagian besar memiliki kesamaan karena struktur kepengurusan Gapoktan terdiri atas ketua, sekretaris, bendahara dan didukung oleh beberapa bidang. Bidang yang terbentuk antara lain: bidang teknologi, bidang sarana produksi pertanian, bidang hubungan masyarakat (humas), bidang pemasaran, dan bidang simpan pinjam.

\section{Sasaran Penyaluran Program PUAP}

Penyaluran Dana BLM-PUAP harus mengutamakan pelayanan yang baik agar dapat menjangkau para petani yang membutuhkannya dengan pembentukan kelembagaan di tiap Gapoktan. secara teknis penyaluran dana yang telah disalurkan ke Gapoktan untuk 
selanjutnya didistribusikan kepada Anggota Gapoktan agar dimanfaatkan dengan berbagai usaha berbasis budidaya pertanian berdasarkan perencanaan yang tertuang dalam RUB (Rapat Usaha Bersama ) dan sesuai dengan AD/ART masing-masing Gapoktan. Hal ini sejalan dengan penelitian terdahulu oleh Kasmadi (2005) yang menyatakan bahwa keberhasilan perguliran Dana PUAP pengaturannya diatur oleh kelompok tani sendiri yang dibawah naungan Gapoktan dan pemerintah serta petugas pendamping karena keberhasilan Program PUAP tidak terlepas dari kesadaran petani dalam mengembangkan usahatani, jika keterlambatan pembayaran angsuran tidak tepat waktu maka akan merugikan petani itu sendiri.

Dana yang sudah di terima Gapoktan kemudian digunakan untuk pengadaan sarana produksi, pupuk, dan obat-obatan. Pembelian faktor produksi ini didasarkan pada kebutuhan petani dalam mengelola dan mengembangkan usahataninya, sementara itu modal yang ada tidak cukup untuk menunjang pengadaan saprodi tersebut, sehingga Dana BLM-PUAP sangat berarti bagi petani dalam kebutuhan pembelian saprodi. Petani yang merupakan Anggota Gapoktan menerima pinjaman Dana BLM-PUAP dalam jumlah yang relative sama dengan yang diajukan dalam RUK (Rencana Usaha Kelompok) dan RUA (Rencana Usaha Anggota), selanjutnya pemanfaatan pinjaman tersebut sepenuhnya diserahkan kepada masing-masing anggota selaku peminjam. Berdasarkan penelitian, Anggota Gapoktan memperoleh pinjaman sebagian besar digunakan untuk menambah modal usahataninya seperti pembelian bibit atau benih, pupuk, obat-obatan dan lain sebagainya.

Pada aspek ekonomi usaha, kendala utama yang sering dihadapi yaitu kurangnya sumber daya dalam pelaksanaan Rencana Usaha Kelompok (RUK) serta masih rendahnya tingkat pengembalian kredit. Pada aspek kelembagaan minimnya pemberdayaan dan perkembangan jumlah anggota kelompok, masih rendahnya tingkat partisipasi dan penyaluran aspirasi anggota serta lemahnya kerjasama yang saling menguntungkan. Identifikasi potensi agribisnis ini dilakukan oleh Penyuluh Pendamping, ketika melakukan penyusunan RUB harus berdasarkan kelayakan usaha produktif petani. Usaha produktif yang ada di daerah penelitian sebagian besar usahatani sayuran dan padi sawah.

RUB yang telah disusun di verifikasi oleh Penyelia Mitra Tani (PMT) untuk disetujui oleh tim teknis kabupaten/kota. RUB yang sudah disetujui selanjutnya dikirim bersama dengan dokumen administrasi pendukung. Untuk lebih lengkapnya dapat dilihat pada skema sistem penyaluran Dana PUAP pada Gambar 1 berikut. 


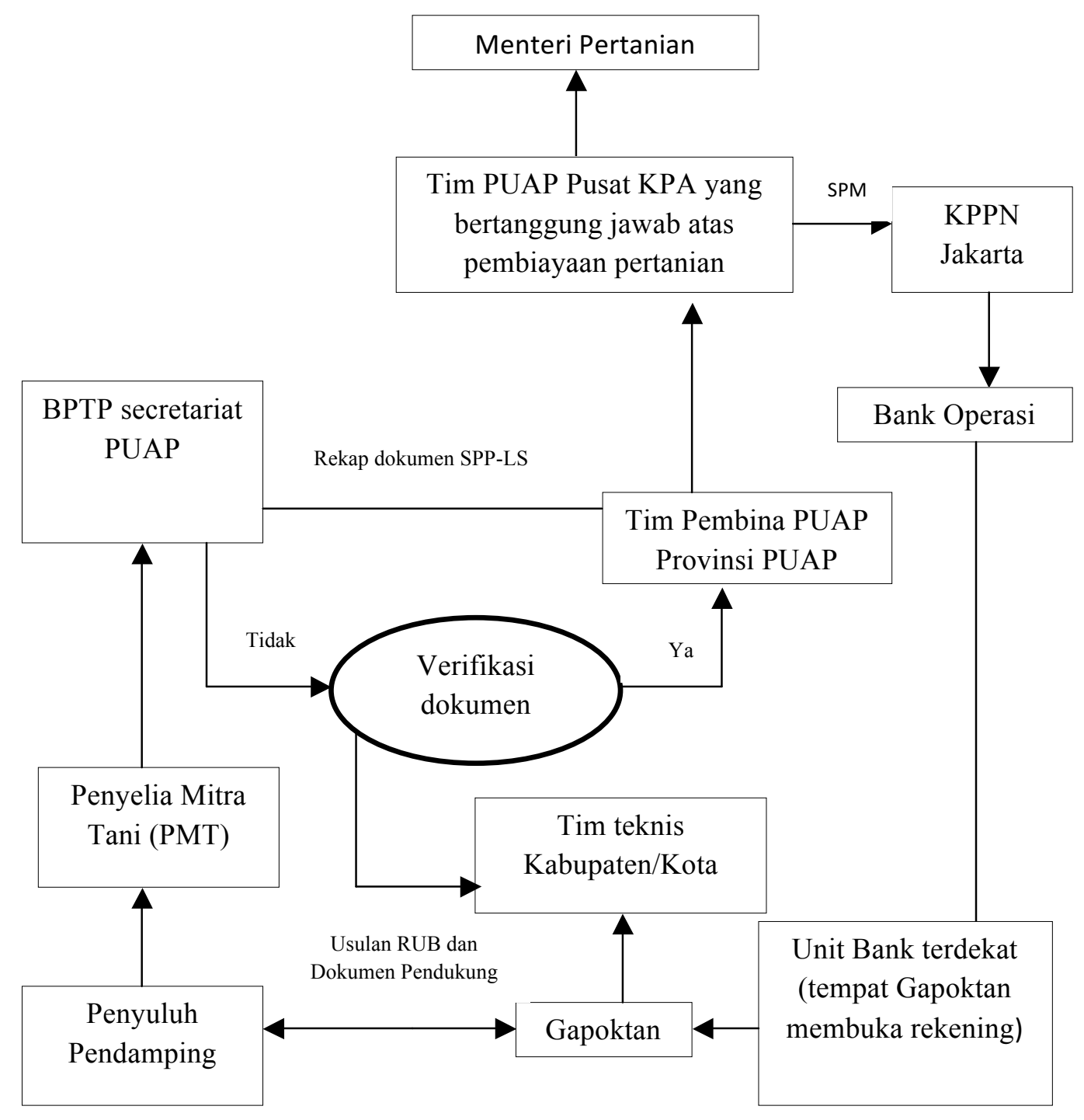

Gambar 1. Sistem Penyaluran Dana PUAP

\section{Mekanisme Pengalokasian Dana PUAP ke Anggota Gapoktan di Daerah Penelitian}

Pengalokasian dan pengembalian modal PUAP di daerah penelitian meliputi adanya sosialisasi program, seleksi calon anggota Gapoktan, penetapan calon anggota Gapoktan, penyaluran Dana PUAP, dan Pengembalian dana PUAP. Untuk lebih jelasnya dapat dilihat pada skema Gambar 2 berikut. 


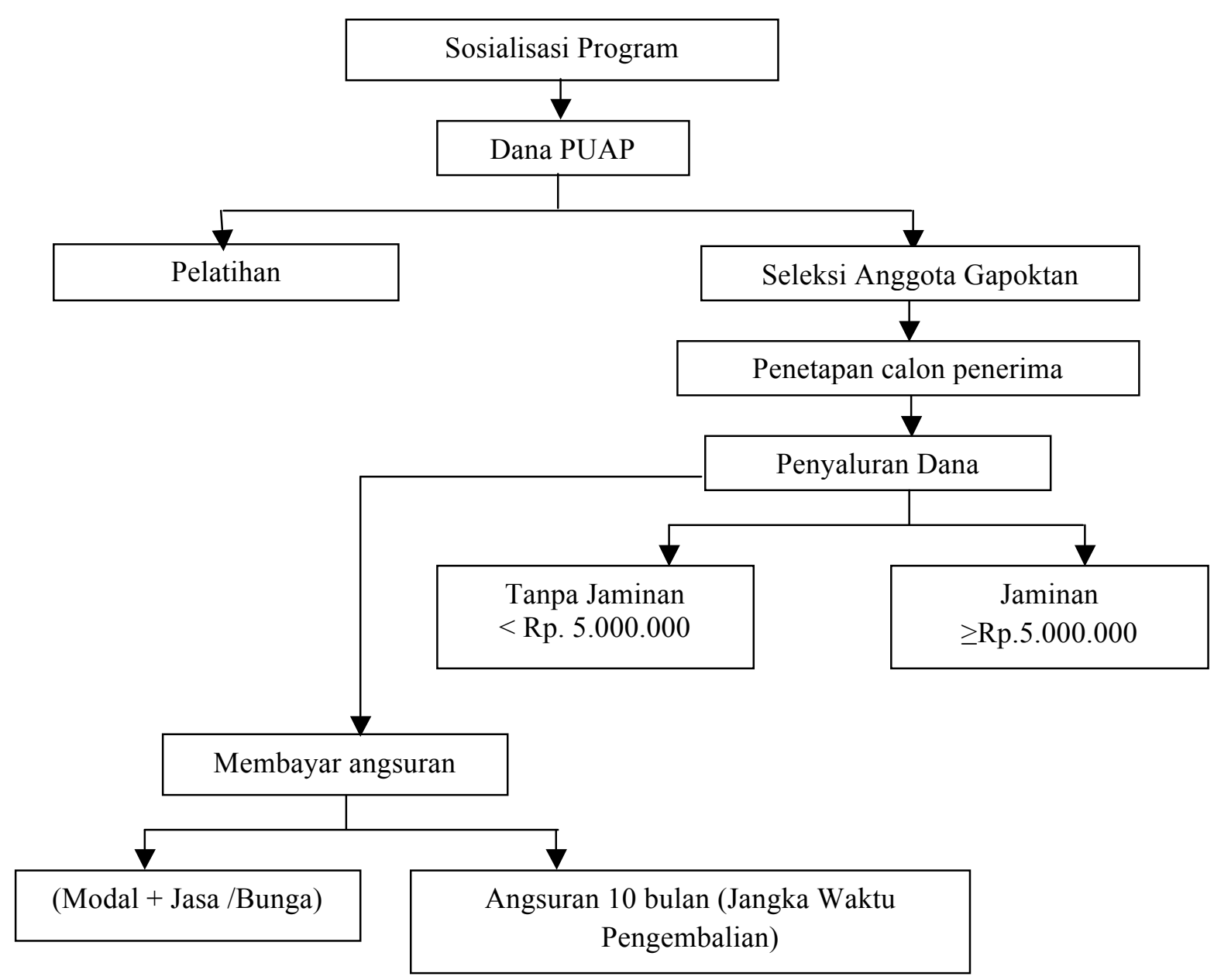

Gambar 2. Skema Mekanisme Pengalokasian Dana PUAP

\section{Tingkat Keberhasilan Kegiatan Usahatani Anggota Gapoktan Pada Pengembangan Usaha Agribisnis Perdesaan (PUAP)}

Tiap Gapoktan yang ditunjuk untuk mengelola dan menyalurkan Dana PUAP harus mengatur Dana PUAP agar benar-benar bermanfaat bagi anggotanya, sehingga anggota Gapoktan dapat mengalokasikan Dana PUAP pada usahatani yang dijalankan. Dana PUAP akan menjadi sarana yang baik apabila dilakukan dengan tepat sasaran dan prosedur pada kegiatan usahatani, apabila Dana PUAP tidak tepat sasaran maka akan berdampak pada keberlanjutan keberhasilan program PUAP. Petani yang menerima Dana PUAP sebagian besar untuk menambah modal usahataninya sebagai salah satu penggerak pokok bagi pengembangan usahatani dan mengurangi ketergantungan petani pada pelepas uang atau tengkulak. Fungsi modal PUAP yang diberikan tidak hanya sebagai salah satu factor produksi, tetapi juga berperan dalam peningkatan kapasitas petani mengadopsi teknologi seperti benih berkualitas, pupuk, alat, dan teknologi pasca panen. Sehingga akan terlihat bahwa modal PUAP benar-benar berhasil mengembangkan usahatani bagi petani.

\section{Keadaan Kelompok Tani}

Berdasarkan data yang diperoleh dari Balai Penyuluhan Pertanian Balai Penyuluhan Pertanian (BPP) serta penyuluh pertanian yang ada di Kecamatan Jambi Selatan ataupun Kecamatan Pelayangan menyebutkan bahwa telah terbentuk 21 kelompok tani yang menaungi 
kegiatan usahatani di Kecamatan Jambi Selatan kemudian di Kecamatan Pelayangan sebanyak 17 kelompok tani. Pada Gapoktan Tani Makmur membentuk 4 kelompok tani yang mengusahakan usahatani sayuran dan mendapatkan Dana Pinjaman PUAP pada tahun 2009, pengelolaan hasil pertanian mendapatkan pinjaman Dana PUAP pada tahun 2014

\section{Luas Lahan Usahatani}

Penelitian yang dilakukan di Kecamatan Jambi Selatan dan Kecamatan Pelayangan menggambarkan bahwa tingkat keberhasilan program PUAP akan dilihat melalui kegiatan usahatani terutama pada peningkatan produksi serta penerimaan petani sehingga peluang untuk peningkatan pendapatan akan lebih besar, karena tujuan program PUAP yaitu memberikan peningkatan pendapatan petani serta memudahkan petani dalam pengadaan sarana produksi. Luas lahan merupakan salah satu faktor penunjang keberhasilan usahatani yang mempengaruhi produksi usahatani. Pada Kecamatan Jambi Selatan sejak dulu sudah dikenal sebagai kawasan pemasok komoditi sayur-sayuran di Kota Jambi, sedangkan di Kecamatan Pelayangan para petaninya dominan dalam berusahatani padi sawah, hal ini dikarenakan menanam padi sawah secara tak langsung adalah warisan budaya dari pendahulu petani yang sudah sejak lama memang menanam padi sawah walaupun pada saat ini petani di Kecamatan Pelayangan juga sudah mulai berusahatani sayuran.

Menurut Hernanto (1996) bahwa luas lahan garapan termasuk faktor utama yang mempengaruhi tingkat produksi dan penerimaan petani. Apabila luas lahan petani cukup besar, peluang ekonomi untuk meningkatkan produksi dan pendapatan akan lebih besar (Soekartawi dkk, 1986). Hasil penelitian terhadap luas lahan Anggota Gapoktan di daerah penelitian dengan luas lahan terkecil $0,1 \mathrm{Ha}$ dan luas lahan terbesar $2 \mathrm{Ha}$. Hal ini menunjukkan bahwa luas lahan di daerah penelitian rata-rata di bawah satu hektar karena semakin menyempitnya lahan di Kota Jambi disebabkan oleh pembangunan yang semakin pesat. Status lahan pada daerah penelitian umumnya adalah sewa dan bagi hasil, karena harga jual lahan yang cukup tinggi yang menyebabkan petani tidak dapat memiliki lahan. Menurut penelitian terdahulu Tita Nursyamsiah (2010) menyatakan bahwa jika penggunaan luas lahan kurang dari 1 ha dapat disimpulkan bahwa responden penerima dana PUAP melakukan skala usaha yang kecil atau sebagian besar skala usaha rendah.

\section{Biaya Produksi Usahatani Anggota Gapoktan}

Biaya produksi merupakan nilai dari berbagai input dalam bentuk benda dan jasa yang digunakan selama berlangsung proses produksi. Hernanto (2006) mengatakan bahwa korbanan yang dicurahkan dalam proses produksi yang semula fisik, kemudian diberi nilai rupiah yang mana disebut dengan biaya. Pada usahatani Anggota Gapoktan terdapat tiga komponen biaya, yaitu biaya pembelian sarana produksi, biaya tenaga kerja, dan biaya penyusutan alat-alat pertanian. Ada tiga macam sarana produksi yang digunakan petani sampel yaitu biaya benih, biaya pupuk dan biaya obat-obatan. Biaya untuk benih yang digunakan petani sampel di daerah penelitian pada usahatani padi sawah merupakan benih yang didapat dari hasil produksi petani, sebelumnya menggunakan benih lokal, kemudian benih yang digunakan untuk sayur-sayuran sebagian besar menggunakan benih yang dipakai dari merk panah merah, untuk pupuk yang digunakan pada usahatani padi sawah petani sebagian besar menggunakan pupuk urea, SP36 dan KCL, kemudian pupuk yang digunakan untuk sayur-sayuran tergantung dari jenis komoditi usahatani yang dikelola, yaitu sebagian besar menggunakan pupuk kandang dan urea, dan obat-obatan yang digunakan pada usahatani padi sawah yaitu menggunakan roundap dan decis, kemudian obat-obatan atau pestisida yang 
digunakan pada usahatani sayuran petani di daerah penelitian sebagian besar menggunakan pestisida merk decis dan curracron.

Biaya produksi selanjutnya yaitu Biaya penyusutan alat pertanian yang diperhitungkan pada Kecamatan Jambi Selatan adalah cangkul, sabit, handsprayer, pompa air, garuk, rotary, kuldifator, pisau. Kemudian di Kecamatan Pelayangan biaya yang diperhitungkan adalah cangkul, sabit, handsprayer. Alat-alat tersebut yang digunakan petani baik dalam usahatani padi sawah maupun usahatani sayuran. Hasil penelitian terhadap biaya penyusutan alat pertanian Anggota Gapoktan di Kecamatan Jambi Selatan dengan biaya penyusutan alat pertanian terkecil sebesar Rp.750 dan biaya penyusutan alat pertanian terbesar adalah Rp. 421.350. kemudian di Kecamatan Pelayangan biaya penyusutan alat pertanian terkecil adalah sebesar Rp. 1500 dan biaya penyusutan terbesar adalah Rp. 15.450, dan biaya yang dikeluarkan berikutnya yaitu biaya tenaga kerja Tenaga kerja adalah faktor produksi yang penting dan perlu diperhitungkan dalam proses produksi dalam jumlah cukup, bukan saja terlihat dari tersedianya tenaga kerja namun kualitas dan macam tenaga kerja juga perlu diperhatikan. Tenaga kerja yang digunakan biasanya berasal dari anggota keluarga. Biaya tenaga kerja dinilai sesuai dengan upah yang berlaku pada setiap petani, biaya tenaga kerja adalah bagian dari biaya penanaman, biaya pemeliharaan dan panen yang dibutuhkan tanaman.

\section{Produksi Usahatani Anggota Gapoktan}

Produksi usahatani Anggota Gapoktan di Kecamatan Jambi Selatan menunjukkan bahwa ada 11 usahatani sayuran yang di usahakan kemudian Anggota Gapoktan yang berada di Kecamatan Pelayangan ada 4 komoditi usahatani yang di usahakan dan rata-rata berusahatani padi sawah dengan rata-rata total produksi $826,73 \mathrm{Kg}$ per tahunnya, sebagian juga berusahatani sayuran keras seperti kacang panjang dengan total produksi rata-rata 416,25 kg per tahunnya, pare dengan total produksi $8500 \mathrm{Kg}$ per tahunnya, dan timun total produksi rata-rata 933,33 kg per tahunnya. Hal ini berbeda dengan Anggota Gapoktan yang berada di Kecamatan Jambi Selatan yang rata-rata berusahatani komoditi sayur-sayuran seperti kacang panjang dengan rata-rata total produksi $700 \mathrm{~kg}$ per tahunnya, kangkung rata-rata total produksi $1.620 \mathrm{Kg}$ per tahunnya, bayam rata-rata total produksi 1.320 per tahunnya, sawi ratarata total produksi $252,35 \mathrm{~kg}$ per tahunnya, selada rata-rata total produksi $376,36 \mathrm{~kg}$ per tahunnya, pare rata-rata total produksi $950 \mathrm{Kg}$ per tahunnya, timun rata-rata total produksi $802,94 \mathrm{Kg}$ per tahunnya, pakcoi rata-rata total produksi 574,29 per tahunnya, kembang kol rata-rata total produksi $250,91 \mathrm{Kg}$ per tahunnya, seledri rata-rata total produksi $224 \mathrm{Kg}$ per tahunnya, dan kemangi rata-rata total produksi $182 \mathrm{Kg}$ pertahunny, karena Kecamatan Jambi Selatan memang merupakan salah satu sentra produksi sayuran yang berada di Kota Jambi. Dalam memproduksi Usahatani petani sangat membutuhkan modal pendukung dalam mengembangkan usahataninya. Sehingga Dana BLM-PUAP yang telah di terima Anggota Gapoktan dapat langsung digunakan dalam realisasi pengembangan usahatani serta di alokasikan ke sarana produksi (Saprodi) pendukung. Hal ini juga sejalan dengan penelitian terdahulu Tita Nursyamsiah (2010) dengan menggunakan variable dummy dan metode OLS diperoleh hasil bahwa produksi penerima BLM-PUAP lebih besar dibandingkan dengan yang tidak menerima PUAP dengan taraf kepercayaan 90 persen dengan faktor-faktor yang mempengaruhi produksi yaitu penggunaan luas lahan, pupuk buatan dan organic, serta obatobatan karena penerima PUAP berpengaruh terhadap produksi disebabkan oleh penerima PUAP memiliki produktivitas lahan yang lebih baik dibandingkan yang tidak menerima Dana PUAP. 


\section{Penerimaan Usahatani Anggota Gapoktan}

Penerimaan usahatani pada penelitian ini dimaksudkan adalah total penerimaan yang berasal dari semua usahatani yang diusahakan petani baik satu maupun lebih komoditi. Penerimaan usahatani dihitung dalam kurun waktu satu tahun. Hernanto (2006) mengatakan penerimaan usahatani adalah hasil produksi pertanian yang diusahakan oleh petani dikalikan dengan harga jual hasil produksi. Hasil penelitian terhadap penerimaan usahatani Anggota Gapoktan di Kecamatan Jambi Selatan menunjukkan bahwa penerimaan usahatani terkecil adalah sebesar Rp. 9.675.000 dan Penerimaan terbesar Rp. 34.710.000, kemudian pada Kecamatan Pelayangan penerimaan usahatani terkecil sebesar Rp. 2.025.000 dan penerimaan usahatani terbesar yaitu sebesar Rp. 54.075.000. berdasarkan hasil penelitian, terlihat bahwa responden yang mengusahakan pertanian dengan menanam berbagai komoditi sayuran menerima penerimaan yang lebih tinggi daripada responden yang hanya mengusahakan komoditi padi sawah, hal ini disebabkan oleh harga untuk komoditi sayuran lebih tinggi dipasaran serta frekuensi tanam petani di daerah penelitian, dimana petani padi sawah di daerah penelitian hanya menanam satu kali dalam satu tahun sedangkan petani yang mengusahakan komoditi sayuran dapat menanam sepanjang tahun, akan tetapi terdapat juga Anggota Gapoktan yang mengusahakan padi sawah dan komoditi sayuran yang membuat penerimaan Anggota Gapoktan dapat lebih tinggi. Hasil penelitian terdahulu oleh Ramdani (2014) mengindikasikan bahwa penerimaan para petani dapat dilihat dari variasi usahatani yang dijalankan. Penerimaan usahatani yang mengusahakan pertanian lebih dari satu komoditi menerima penerimaan lebih besar dibandingkan petani yang hanya mengusahakan satu macam usahatani misalnya hanya menanam padi sawah, hal ini dikarenakan harga untuk komoditi ragam usahatani misalnya sayuran yang lebih tinggi dipasaran serta frekuensi tanam petani.

\section{Pendapatan Usahatani Anggota Gapoktan}

Pendapatan diartikan sebagai selisih antara besarnya penerimaan dan biaya yang dikeluarkan. Selain itu pendapatan dapat digambarkan sebagai balas jasa dan kerja sama faktor-faktor produksi yang disediakan oleh petani sebagai penggerak, pengelola, pekerja dan sebagai pemilik modal. Tingkat Keberhasilan dari kegiatan usahatani program PUAP dapat dilihat dari pendapatan bersih yang diperoleh petani dan kaitan modal di dalamnya. Pendapatan Anggota Gapoktan yang dimaksud dalam hal ini adalah pendapatan yang diterima Anggota Gapoktan dalam satu tahun. Hasil penelitian terhadap rata-rata pendapatan Anggota Gapoktan pada di Kecamatan Jambi Selatan sebesar Rp. 1.939.322,53 per musim tanamnya dan rata-rata pendapatan di Kecamatan Pelayangan adalah sebesar Rp. 3.948.505,22 per musim tanamnya.

\section{KESIMPULAN}

Berdasarkan hasil penelitian terhadap kaitan Bantuan Langsung Masyarakat (BLM) Pengembangan Usaha Agribisnis Perdesaan (PUAP) dapat disimpulkan bahwa proses penyaluran Dana BLM-PUAP melalui beberapa syarat prosedure dengan memenuhi jasa mulai dari 1 persen sampai dengan 2,5 persen di tiap bulannya, Dana PUAP juga memiliki pengaruh dalam pengadaan sarana produksi usahatani dengan faktor-faktor yang mempengaruhi produksinya yaitu luas lahan, pupuk, serta obat-obatan. Dari hasil penelitian bahwa program PUAP yang dilaksanakan di Gapoktan daerah penelitian dinyatakan belum berhasil secara keseluruhan, karena mekanisme penyaluran yang dianggap masih belum efektif sehingga perkembangan Dana PUAP dinilai belum maksimal. Untuk pendapatan dapat 
disimpulkan bahwa pendapatan Anggota Gapoktan di Kecamatan Pelayangan jauh lebih kecil dibandingkan dengan Kecamatan Jambi Selatan.

\section{UCAPAN TERIMA KASIH}

Pada kesempatan ini penulis ingin menyampaikan terima kasih kepada Sekretaris Jurusan, serta Ketua Program Studi Agribisnis Fakultas Pertanian Universitas Jambi yang telah memfasilitasi pelaksanaan penelitian ini. Selain itu ucapan terima kasih kepada Camat Jambi Selatan, Camat Pelayangan, Bapak Lurah Lingkar Selatan, Bapak Lurah Mudung Laut, PPL Kelurahan Lingkar Selatan, dan PPL Kelurahan Mudung Laut yang memfasilitasi pelaksanaan penelitian di lapangan.

\section{DAFTAR PUSTAKA}

Badan Pusat statistic. 2014. Data dan Informasi Kemiskinan. Jakarta : Badan Pusat Statistik

Badan Pusat Statistik. 2013. Statistik Daerah Kota Jambi 2013. Jambi : Badan Pusat Statistik

Dinas Pertanian. 2013. Profil Kinerja Gapoktan PUAP. Provinsi Jambi.

Fitria. 2007. Evaluasi Program Bantuan Pinjaman Langsung Masyarakat Sapi Potong di Kabupaten agam, Sumatera Barat. Skripsi Fakultas Pertanian, Institut Pertanian Bogor

Hernanto. F. 1996. Ilmu Usahatani. Penebar Swadaya. Jakarta

Hernanto, U. B. 2006. Ilmu Usahatani. Penebar Swadaya. Jakarta

Kasmadi. 2005. Pengaruh Bantuan Langsung Masyarakat Terhadap Kemandirian Petani Ternak. Skripsi Fakultas Pertanian, Institut Pertanian Bogor.

Kementrian Pertanian. 2014. Pedoman PUAP Pengambangan Usaha Agribisnis Perdesaan. No. 01/Permentan/OT.140/1/2014. Jakarta.

Nursyamsiah, Tita. 2010. Pengaruh Program Pengembangan Usaha Agribisnis Perdesaan (PUAP) Terhadap Produksi dan Pendapatan Usahatani Padi (Studi Kasus Pada Anggota Gapoktan Mekarsari, Desa Purwasari, Kecamatan Darmaga, Kabupaten Bogor Jawa Barat)

Prihartono, Koko. 2009. Dampak Program Pengembangan Usaha Agribisnis Perdesaan Terhadap Kinerja Gapoktan dan Pendapatan Anggota Gapoktan di Kabupaten Tanjung Jabung Barat. Skripsi Fakultas Pertanian Institut Pertanian Bogor. Bogor. 158 halaman.

Ramdani, Danil. 2014. Hubungan Pendapatan Dengan Alokasi Konsumsi Rumah Tangga Petani di Kota Jambi. Skripsi Fakultas Pertanian Universitas Jambi.

Riduwan, dan Akdon. 2009. Rumus dan Data Dalam Analisis Statistika. Penerbit Alfabeta. Bandung.

Siadari Marista Ida, 2015. Peranan Kredit Koperasi Unit Desa Terhadap Peningkatan Pendapatan Nasabah di Kecamatan Sungai Bahar Kabupaten Muaro Jambi. Skripsi Fakultas Pertanian Universitas Jambi.

Setiaji, Haryo. Dampak Program Pengembangan Usaha Agribisnis Perdesaan Terhadap Pendapatan Anggota Gabungan Kelompok Tani (Studi Kasus : Desa Banyukuning Kecamatan Bandungan, Kabupaten Semarang). Skripsi Fakultas Ekonomika dan Bisnis Universitas Diponegoro Semarang. 2013.

Soekartawi. 1986. Ilmu Usahatani. Universitas Indonesia Press. Jakarta 